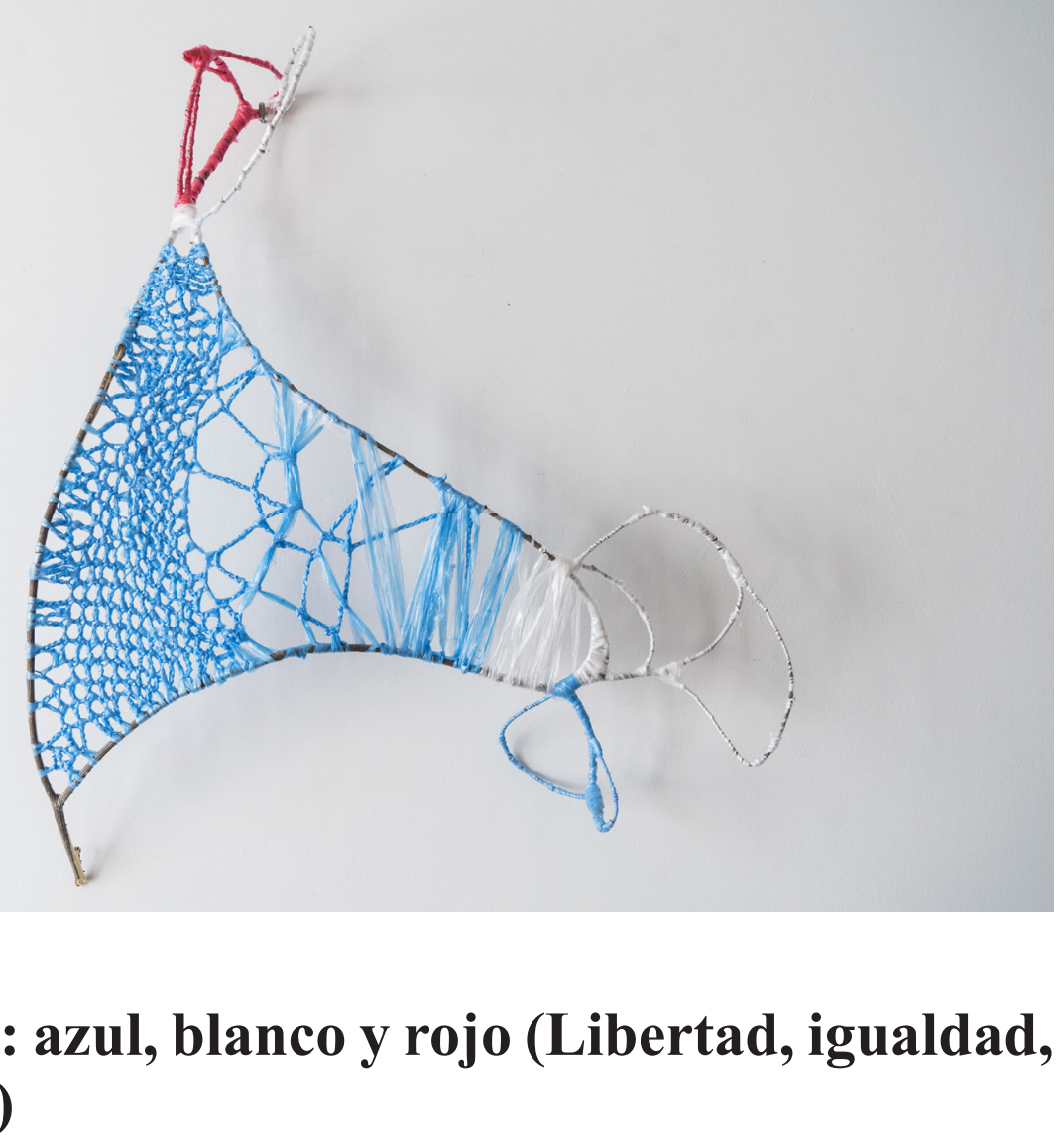

\title{
Tres colores: azul, blanco y rojo (Libertad, igualdad, fraternidad)
}

\section{Técnica}

Escultura: bolsas de plástico que han servido como guantes para comprar y madera.

\section{Reflexión}

Con la crisis del Covid19 se están utilizando más plásticos, el plástico lo envuelve todo, es casi imposible evitarlo.

La artista quiere expresar y denunciar con esta pieza su preocupación por la contaminación que estamos provocando con los nuevos residuos procedentes del nuevo tipo de vida que ha provocado la pandemia a nivel internacional.

\section{Autora}

Charo Corrales trabaja la fotografía como medio de expresión, pero como artista multimedia también emplea para sus creaciones diferentes técnicas y soportes, desde la cerámica al bordado, el video, el performance, la instalación, y la intervención de espacios. También la artista trabaja el concepto de re-utilizar objetos (desechables) para sus proyectos artísticos.

Hasta la fecha, el eje central de sus trabajos es la identidad personal o colectiva en aspectos tan variados como el cuerpo, la edad, la pertenencia al grupo, la emigración, la inmigración, la feminidad y la relación con la naturaleza.

Arteterapia: papeles de arteterapia y educación artística para la integración social. Monográfico: Las miradas del arte y el arteterapia en tiempos de la Covid19. ISSN-e: 1988-8309 https://dx.doi.org/10.5209/arte.75912 